\title{
A Case of Cochlear Implantation in a Patient With Intracochlear Schwannoma
}

\author{
Hye Ah Joo (iD) and Hong Ju Park iD \\ Department of Otorhinolaryngology-Head and Neck Surgery, Asan Medical Center, University of Ulsan College of Medicine, \\ Seoul, Korea
}

와우내 신경초종 환자에서 시행한 인공와우 이식술 1 예

주혜아 · 박홍주

울산대학교 의과대학 서울아산병원 이비인후-두경부외과학교실

\author{
Received June 21, 2021 \\ Revised August 24,2021 \\ Accepted August 31, 2021 \\ Address for correspondence \\ Hong Ju Park, MD, PhD \\ Department of Otorhinolaryngology- \\ Head and Neck Surgery, \\ Asan Medical Center, \\ University of Ulsan \\ College of Medicine, \\ 88 Olympic-ro 43-gil, Songpa-gu, \\ Seoul 05505 , Korea \\ Tel $+82-2-3010-3700$ \\ Fax $+82-2-489-2773$ \\ E-mail dzness@amc.seoul.kr
}

Intralabyrinthine schwannomas are rare benign tumors, which arise from neural portions within the labyrinth. These are subclassified into seven groups according to the affected inner ear structures. Intracochlear schwannomas (ICS) are tumors confined to the cochlea, and these can cause progressive unilateral sensorineural hearing loss, tinnitus, vertigo and aural fullness. Here, we report a 49-year-old female patient with left sudden sensorineural hearing loss. There was no improvement of hearing despite steroid and hyperbaric oxygen therapy. Space occupying lesion in the basal turn of the left cochlea was identified in MRI with enhancement. She underwent tumor removal through an extended round window approach, and cochlear implantation was performed successfully. This is the first case report of cochlear implantation after tumor removal in a patient with ICS in Korea, and we discuss management options with a review of the literature.

Korean J Otorhinolaryngol-Head Neck Surg 2022;65(2):116-20

Keywords Cochlea; Cochlear implantation; Schwannoma; Sudden hearing loss.

\section{서 론}

8번 뇌신경에서 기인하는 신경초종(schwannoma)은 내이 도나 소뇌교각에서 주로 발생하나, 미로내 신경초종은 전정, 와우 또는 반고리관을 포함한 미로에 100만 명당 2.6명의 빈 도로 드물게 발생하는 종양이다. ${ }^{1-6)}$ 이 중 와우내 신경초종은 와우내 신경섬유 말단 부위에서 발생하여 와우내에 국한된 종양으로, 미로내 신경초종 중에서도 $22 \%-28 \%$ 의 빈도로 보 고된다. 와우내 신경초종은 여러 가지 임상 양상을 보이며, 가 장 흔한 증상은 일측성 청력 저하(93\%-100\%)로 이명(50\%), 어지럼(30\%-51\%), 이충만감 등이 동반될 수 있다. ${ }^{1,2,7,8)}$

This is an Open Access article distributed under the terms of the Creative Commons Attribution Non-Commercial License (https://creativecommons.org/licenses/by-nc/4.0) which permits unrestricted non-commercial use, distribution, and reproduction in any medium, provided the original work is properly cited.
국내에서는 2009년 Park 등'에 의해 와우내 신경초종 2예 에 대해서 첫 보고된 바가 있으나, 종양을 제거한 후 성공적 으로 청각 재활을 위한 인공와우 이식술 시행을 한 환자는 아직까지 보고된 바가 없다. 최근 저자들은 와우내 신경초종 이 확인된 일측성 감각신경성 난청 환자에서 성공적으로 종 양을 제거하고 합병증 없이 인공와우 이식술을 시행하였기에 이를 문헌 고찰과 함께 이를 보고하고자 한다.

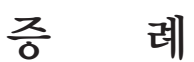

특이 병력 없는 49세 여자 환자가 9개월 전 발생한 좌측 난 청을 주소로 본원에 내원하였다. 내원 당시 좌측 난청 및 이 명 이외 이통, 이루, 어지럼, 이충만감 등의 이과적 증상은 호 소하지 않았고, 양측 고막은 정상 소견을 보였다. 순음청력검 
사(pure tone audiometry, PTA)에서 좌측 기도청력은 $76 \mathrm{~dB}$ $\mathrm{HL}$, 단음절어 단어인지점수(word recognition score, WRS) 는 $8 \%$ 였으며, 우측 기도청력은 $7 \mathrm{~dB} \mathrm{HL}$ 로 좌측 일측성 감각 신경성 난청이 확인되었다. 과거력상 환자는 타원에서 MRI를 포함한 검사를 통해 좌측 미로염(labyrinthitis)으로 진단 받 았으며, 좌측 돌발성 난청에 대하여 경구 스테로이드 복용 및 좌측 고실내 스테로이드 주입술을 시행 받았으나 증상 호전 이 없었다. 환자는 추가 치료를 강력하게 원하여 본원에서 고 압산소치료를 시행하였으나 청력의 호전은 없었다. 추가적인 청각 재활을 위해 $\mathrm{CROS}$ 보청기, 골도 보청기, 인공와우 수술 의 장단점을 환자에게 설명하였고, 환자는 좌측 인공와우 이 식술을 시행하기로 결정하였다.

수술 전 재시행한 PTA에서 좌측 기도청력 $94 \mathrm{~dB} \mathrm{HL}$, WRS는 최대 자극에도 $8 \%$ 였고, 우측 기도청력 $7 \mathrm{~dB} \mathrm{HL}$ 로 좌측 전농 소견을 보였다(Fig. 1). 비디오 두부충동검사, 온도 안진검사상에서 특이 소견은 관찰되지 않았다. 수술 전 시행 한 측두골 전산화단층촬영(temporal bone $\mathrm{CT}$ )에서 이상 소 견은 없었으며, 본원에서 수술 전 와우와 청신경의 자세한 해 부학적 특징을 확인하기 위해 시행한 조영 증강이 없는 proton-density (PD) weighted MRI에서 양측 청신경은 잘 관찰 되었으나 좌측 와우 기저회전(basal turn)에 충만 결손이 확 인되었다(Fig. 2). 보다 정확한 병변의 확인을 위해 과거 타원 에서 촬영한 측두골 $\mathrm{MRI}$ 를 환자에게 요청하여 확인한 결과, $\mathrm{T} 1$ 강조영상에서 좌측 와우 기저회전에 가돌리늄 조영 증강 이 되는 병소가 관찰되었으며, $\mathrm{PD}$ 및 T2 강조영상에서 저신

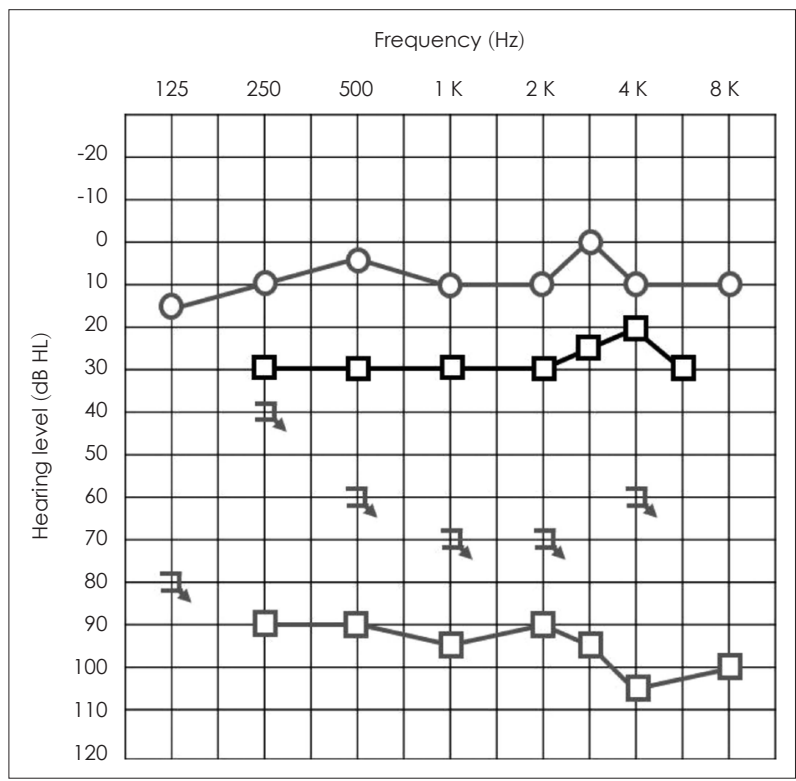

Fig. 1. PTA of the patient with left intracochlear schwannoma. Preoperative (gray) and six-week postoperative (black) PTA. PTA, pure tone audiometry.
호강도를 보이는 공간점유병소가 좌측 와우 기저회전에서 관 찰되어 와우내 신경초종을 확인할 수 있었다(Fig. 2). 따라서 환자에게는 와우내 종양을 제거한 후에 인공와우 이식술을 시행할 예정임을 설명하였고, 수술을 시행하였다.

전신마취하 좌측 유양돌기 절제술(mastoidectomy) 및 후 고실개방술(posterior tympanotomy)을 시행하여 안면신경와 (facial recess)를 통해 접근하였고 정원창(round window)을 통해 와우내 종양을 확인할 수 있었다. 드릴을 이용하여 와우 관을 따라 정원창의 위아래를 최소한으로 노출하여 종양의 경계를 충분히 확인하며 제거하였다(Fig. 3). 병변은 주로 고 실계(scala tympani)에 위치하였고, 종양의 크기가 수술 전 촬영한 영상에서 4-5 mm로 추정되어, 일반적인 후고실개방 술을 통해 정원창 주변의 시야를 충분하게 얻을 수 있었다. 와우의 추가 손상을 방지하고, 최소한의 노출을 통해 고실계 에 존재하는 종양을 제거하기 위해, 정원창 부위의 와우벽을 점차적으로 제거하며 종양의 경계를 확인하였다. 이후 가장
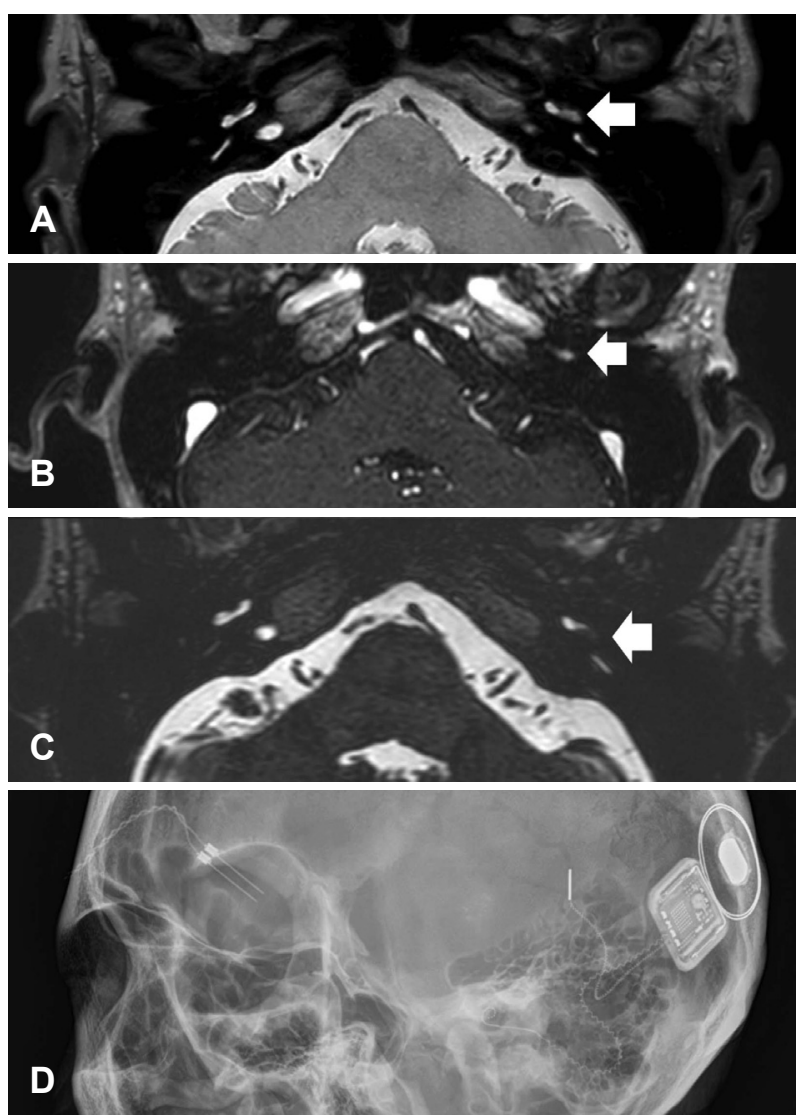

Fig. 2. Preoperative MR images and intraoperative simple X-ray. A: Space occupying lesion (arrow) in basal turn of left cochlea on proton-density weighted image. B: Enhanced mass (arrow) was identified in basal turn of left cochlea on T1-weighted, Gd-enhanced image. C: The defect (arrow) in the high signal intensity of the cochlea filled with fluid was identified in basal turn of left cochlea on T2-weighted image. D: Skull X-ray showing the inserted perimodiolar electrodes of the cochlear implant. 

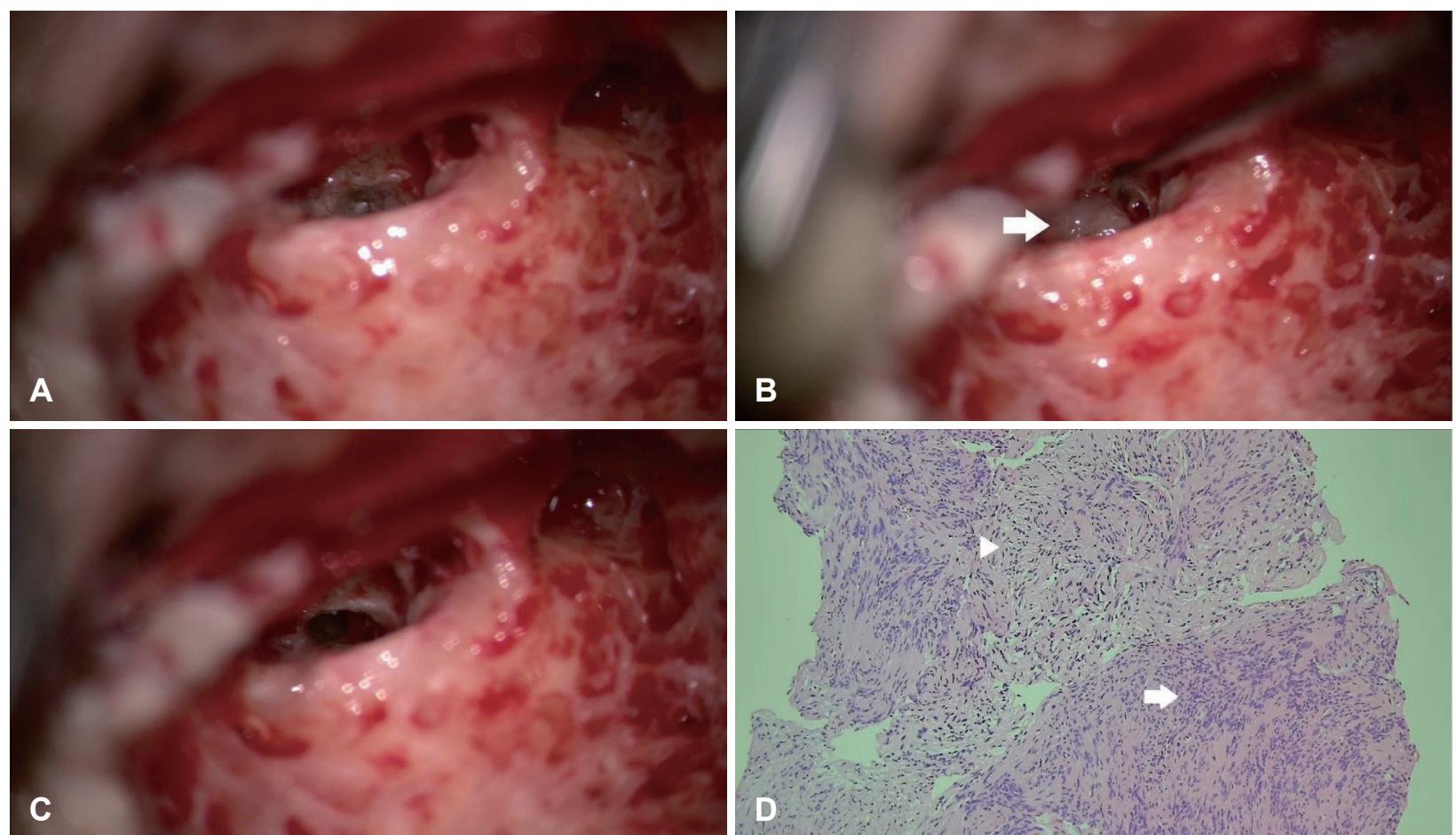

Fig. 3. Intraoperative microscopic views of the tumor and histologic findings. A: After posterior tympanotomy, round window was identified. B: The arrow indicates intracochlear mass in the scala tympani exposed after the bony drilling below the round window along the cochlear basal turn. C: Widely opened cochlear basal turn after the mass had been removed completely. D: The tumor has typical histologic features of the schwannoma. The arrow indicates compact hypercellular Antoni A area and the arrowhead indicates myxoid hypocellular Antoni B area. ( $\times 100$, hematoxylin and eosin stain).

작은 크기의 석션팁(suction tip)과 수직픽(right-angled pick) 을 이용하여 종양의 경계를 확인하면서 종양을 정상 구조물 에서 분리하여 제거하였고, 와우축(modiolus)은 보존되었다. 종양 제거 후 육안적 뇌척수액 유출의 소견은 없었으며, 인공 와우 전극을 개방된 와우의 고실계를 통하여 저항 없이 삽입 하였다. 인공와우 전극은 정원창 주변 골조직을 제거하였기 때문에 직선형 전극(straight type)을 사용할 경우 와우축에 서 너무 멀어지는 단점이 있을 수 있어, 와우축에 가깝게 전 극이 위치할 수 있는 포옹형 전극(modiolus-hugging type) 을 사용하였다. 종양 제거를 위해 개방된 전극 삽입 부위 주 변의 와우 개창 부위를 연부 조직으로 막았다. 전극 삽입 직 후 수술장에서 전극의 임피던스 값과 유발복합활동전위 (evoked compound action potential)의 역치값을 확인하였 고, 22개의 전극 모두에서 정상 임피던스값과 역치값이 확인 되었다. 수술장에서 시행한 두개골 엑스레이 검사상에서도 전극이 잘 삽입됨을 확인하였다(Fig. 2). 종양은 조직검사 결 과상 신경초종으로 진단되었다(Fig. 3). 환자는 수술 후 4일간 주관적 어지럼을 호소하였으나, 수술 후 6일째 어지럼이 호전 되고 수술 부위 상처에 특이 소견이 없어 퇴원하였다. 수술 3 주 후 좌측 귀의 인공와우 착용 청력 역치는 $24 \mathrm{~dB} \mathrm{HL}$ 로 개선되었고, WRS는 $56 \%$ 로 증가하였다. 수술 6 주 후 청력
역치는 $28 \mathrm{~dB} \mathrm{HL}, \mathrm{WRS}$ 는 $56 \%$ 였고, 문장인지검사에서는 98\%의 인지도 호전을 보였다(Fig. 1).

\section{고 찰}

와우내 신경초종은 와우내 신경섬유 말단에서 유래하는 드문 종양이다. ${ }^{1,25-10)}$ 청신경의 슈반세포(Schwann cells)는 나 선신경절(spiral ganglion)과 가까이에 위치한 와우축(modiolus)에도 존재하므로, 주로 와우축에서 와우내 신경초종이 발생하고 성장하여 와우 기저회전의 공간을 점유하거나 전정, 내이도 등으로 자라 들어갈 수 있다. ${ }^{2,11}$ 와우내 신경초종은 미로내 신경초종의 한 형태로서, 와우 기저부에서 흔하게 관 찰된다.17) Kennedy 등은 종양이 국한된 위치에 따라 미로내 신경초종을 전정내 신경초종, 와우내 신경초종, 전정와우내 신경초종, 와우축을 침범한(transmodiolar) 신경초종, 평형반 을 침범한(transmacular) 신경초종, 골성 이낭을 침범한(transotic) 신경초종, 중이를 침범한(tympanolabyrinthine) 신경초 종을 포함한 7군으로 분류하였다. 이들의 보고에 따르면 미 로내 신경초종 중 전정내 신경초종이 $38 \%$ 로 가장 많았으며, 와우내 신경초종은 $28 \%$ 로 확인되었다.

일반적으로 돌발성 난청 환자에서 내이도 및 소뇌교각에 
신경초종이 확인되는 경우는 문헌마다 $1.9 \%-4.9 \%$ 까지 다양 하나 대략 평균 $3.9 \%$ 정도로 보고되며, ${ }^{12,13)}$ 미로내 신경초종 은 100 만 명당 2.6 명의 빈도로 매우 드물게 발생한다. MRI의 등장 전 미로내 신경초종은 어지럼을 조절하기 위한 내이의 수술적 치료 과정 중이나, 사후 부검 시에 우연히 발견되곤 하였다. 오늘날 MRI의 발전으로 $2 \mathrm{~mm}$ 이하의 작은 와우내 병변도 충분히 발견이 가능하고, 종양의 정확한 위치 또한 확 인할 수 있게 되었다. 와우내 신경초종은 주로 $\mathrm{T} 1$ 강조영상에 서 경계가 명확하며 균일하게 조영 증강이 되고, $\mathrm{T} 2$ 강조영상 에서 저신호 강도를 보이게 된다. ${ }^{1,26-11)}$ 따라서 일측성 감각신 경성 난청이 있는 환자에서 종양의 가능성에 대하여 염두하 여 영상을 촬영하고, 소뇌교각부와 내이도뿐만 아니라 와우 와 전정을 세심하게 관찰하여 미로염, 출혈 등과 감별 진단을 하여 잘못된 진단을 하지 않도록 조심하고, 진단이 될 경우 적절한 치료를 계획하는 것이 중요하다. ${ }^{2)}$

와우내 신경초종은 수술적 제거를 하거나 정기적인 MRI 촬영을 통한 경과 관찰을 시행할 수 있는데, 치료 방향은 종 양의 크기, 위치, 성장 속도 및 환자의 잔존 청력, 주관적 증 상, 전신 상태 등을 모두 고려하여 결정하여야 한다.1,2,6-11) 수 술적 접근 방법으로는 경이 접근법 및 경미로 접근법을 통하 여 종양을 제거할 수 있다. 수술을 시행하기 어려우나 종양이 점진적으로 자라는 경우에는 정위방사선치료를 고려할 수도 있다. $2,9,10)$

본 증례는 정원창 접근을 통하여 와우내 신경초종을 제거 하고 인공와우 이식술까지 시행한 예로, 아직까지 와우내 신 경초종 환자에서 어느 정도의 병변 침범 범위를 보일 때 인 공와우 이식술을 시행할 지에 대한 표준적인 지침은 없다. Carlson 등흐는 원발성 내이 신경초종이 확인되었거나, 2형 신 경섬유종증으로 진단 받은 환자 중 청신경초종이 내이의 와 우축을 침범한 10 개의 귀(9명의 환자)들에 대하여, 와우내 종 양은 모두 그대로 남긴 채로 인공와우 이식술을 시행하였다. 수술은 환자에 따라 와우개창술, 정원창 접근법, 확장 정원창 접근법을 통하여 시행하였고, 각각 15 년, 22 년의 오랜 기간 동안 난청이 있었던 2 명의 환자들을 제외하고는 수술 후 좋 은 결과를 얻었다고 보고하였다. 이들에 따르면 종양이 동반 된 귀의 청신경 자체에 문제가 없는 경우, 와우 및 전정 내 신 경초종을 제거하지 않고도 인공와우 이식술을 충분히 시행 할 수 있다고 하였다. 그러나 아직까지 이러한 환자들의 장기 적인 보고가 없는 상태로, 서서히 자라는 신경초종의 특성을 고려할 경우 장기적인 관점에서 청력의 악화를 예상할 수 있 다. Plontke 등 ${ }^{4}$ 은 8명의 와우내 신경초종 환자들을 대상으 로 부분적 와우절제술을 통한 종양 제거 후 인공와우 이식 술을 시행하였고, 수술 6 개월 후 시행한 청력 검사상 유망한
결과를 확인하였다. 이들은 장기적인 경과 관찰을 통한 청각 재활의 효과 파악이 필요하다며, 수술 이후에도 정기적 MRI 촬영을 통하여 종양의 재발이나 잔여 종양의 성장을 관찰하 는 것이 중요하다고 주장하였다. 그러나 최근 개발된 인공와 우 기기가 MRI의 촬영에는 문제가 없는 것으로 보고되지만, 인공와우 기기 자체에 의한 MRI 영상의 왜곡이 유발되어 정 확하게 신경초종의 재발을 평가하는 데 한계가 있을 것으로 생각된다. 따라서 저자들은 와우축을 침범하지 않고 와우관 에만 국한된 와우내 신경초종으로, 와우축을 손상하지 않는 수술적 접근법을 통해 종양의 제거가 보장되는 경우를 와우 내 신경초종 환자에서 가장 이상적인 인공와우 이식술의 적 응증으로 생각한다.

결론적으로 와우내 신경초종은 일측성 감각신경성 난청 환 자에서 드물지만 의심해야 하는 질환 중 하나이며, MRI를 촬 영할 경우 내이도와 소뇌교각에서의 병변뿐 아니라 미로내 종양의 존재를 확인할 필요가 있다. 와우내 신경초종으로 인 하여 고심도 난청이 발생한 경우, 와우축을 보존하며 종양을 제거한 후 인공와우 이식술을 통한 청각 재활은 효과적인 치 료법의 하나로 생각된다.

\section{Acknowledgments}

None

\section{Author Contribution}

Conceptualization: Hye Ah Joo, Hong Ju Park. Data curation: Hye Ah Joo. Formal analysis: Hong Ju Park. Investigation: Hye Ah Joo. Methodology: Hye Ah Joo, Hong Ju Park. Project administration: Hong Ju Park. Resources: Hong Ju Park. Supervision: Hong Ju Park. Writing - original draft: Hye Ah Joo. Writing — review \& editing: Hye Ah Joo, Hong Ju Park.

\section{ORCIDs}

Hong Ju Park https://orcid.org/0000-0002-6331-8556 Hye Ah Joo https://orcid.org/0000-0002-2830-2145

\section{REFERENCES}

1) Kennedy RJ, Shelton C, Salzman KL, Davidson HC, Harnsberger HR. Intralabyrinthine schwannomas: Diagnosis, management, and a new classification system. Otol Neurotol 2004;25(2):160-7.

2) Bittencourt AG, Alves RD, Ikari LS, Burke PR, Gebrim EM, Bento RF. Intracochlear schwannoma: Diagnosis and management. Int Arch Otorhinolaryngol 2014;18(3):322-4.

3) Carlson ML, Neff BA, Sladen DP, Link MJ, Driscoll CL. Cochlear implantation in patients with intracochlear and intralabyrinthine schwannomas. Otol Neurotol 2016;37(6):647-53.

4) Plontke SK, Kösling S, Rahne T. Cochlear implantation after partial or subtotal cochleoectomy for intracochlear schwannoma removal—a technical report. Otol Neurotol 2018;39(3):365-71.

5) Van Abel KM, Carlson ML, Link MJ, Neff BA, Beatty CW, Lohse $\mathrm{CM}$, et al. Primary inner ear schwannomas: A case series and systematic review of the literature. Laryngoscope 2013;123(8): 1957-66. 
6) Jeon H, Chae H, Lee H, Seo YJ. A case of intralabyrinthine schwannoma and literature review of the cases reported previously in Korea. Korean J Otorhinolaryngol-Head Neck Surg 2020;63(6): 270-5.

7) Park MW, Jang JH, Park MH. Two cases of intracochlear schwannoma. Korean J Otorhinolaryngol-Head Neck Surg 2009; 52(12):996-1000.

8) Choi JY, Son EJ, Choi HS, Kim KS. Two cases of intralabyrinthine schwannoma. Korean J Otorhinolaryngol-Head Neck Surg 2006; 49(4):434-8.

9) Kim YH, Jun BC, Yun SH, Chang KH. Intracochlear schwannoma extending to vestibule. Auris Nasus Larynx 2013;40(5):497-9.
10) Plontke SK, Rahne T, Pfister M, Götze G, Heider C, Pazaitis N, et al. Intralabyrinthine schwannomas. HNO 2017;65(Suppl 2):136-48.

11) Yoshida T, Sone M, Naganawa S, Nakashima T. Accuracy of 3.0 Tesla magnetic resonance imaging in the diagnosis of intracochlear schwannoma. Auris Nasus Larynx 2011;38(4):551-4.

12) Fujita T, Saito K, Kashiwagi N, Sato M, Seo T, Doi K. The prevalence of vestibular schwannoma among patients treated as sudden sensorineural hearing loss. Auris Nasus Larynx 2019; 46(1):78-82.

13) Plontke SK. Diagnostics and therapy of sudden hearing loss. GMS Curr Top Otorhinolaryngol Head Neck Surg 2017;16:Doc05. 